\title{
RADIOLOGY PERSPECTIVE: ONE-YEAR STUDY OF HIRSCHSPRUNG DISEASE
}

\author{
Pande Putu Yuli Anandasari ${ }^{1}$, Anastasia Tjan ${ }^{2 *}$, Ni Nyoman Widyasari ${ }^{2}$ \\ ${ }^{1}$ Pediatric Radiology Consultant, Department of Radiology ${ }^{2}$ Department of Radiology, Faculty of Medicine, \\ Udayana University, Sanglah Public General Hospital, Denpasar-Bali, Indonesia
}

\section{ABSTRACT}

Hirschsprung disease is a rare developmental disorder of the enteric nervous system. This study purposed to give an epidemiological database and current trend analysis from radiological perspective of Hirschsprung disease. A prospective descriptive study was conducted for a year in 2017 at Sanglah Public General Hospital, Bali. Colon in loop examination using either water-soluble or barium was conducted. The parameters evaluated in this study were all baseline characteristics, contrast media used, and HD types. Hirschsprung accounted for $2.16 \%$ from all 1018 newborn. Male was 3.4 times more prone to Hirschsprung disease. Age distribution was predominant during $0-4$ weeks after birth (36.4\%). Ultrashort, short, and long segments were $45.5 \%, 45.5 \%$, and $9 \%$ respectively. Contrast media was used and mainly barium rather than water soluble in a proportion of 8:3 due to standard operating procedure adapted by some pediatric surgeon. Ultrashort and short segment HD had the same contribution. Barium was dominated, although water soluble was chosen in most literatures for infant due to its ability as diagnostic as well as therapeutic effect. Hence, further research was expected to support and change the perspective in making the diagnosis.

Keywords: hirschsprung disease; colon in loop; barium enema; pediatric; radiology

\section{ABSTRAK}

Penyakit Hirschsprung merupakan kelainan perkembangan yang menyerang sistem saraf system enterik yang jarang. Tujuan studi ini untuk memberikan gambaran epidemiologi penyakit Hirschsprung dari sudut pandang radiologi Metode penelitian ini bersifat deskriptif prospektif yang dilakukan selama satu tahun pada tahun 2017 di Rumah Sakit Umum Pusat Sanglah (RSUP Sanglah). Pemeriksaan colon in loop digunakan sebagai tombak pada diagnosis penyakit Hirschsprung baik menggunakan kontras barium atau water-soluble. Seluruh karakteristik dasar, kontras media yang digunakan, tipe segmen Hirschsprung merupakan parameter yang dievaluasi. Angka kejadian Hirscpsprung disease di RSUP sanglah pada tahun 2017 adalah $2.16 \%$ dari 1018 bayi lahir hidup. Predileksi usia 0-4 minggu setelah lahir 36,4\%, dominasi laki-laki (77\%). Ultrashort,short, long segment yang ditemukan sebanyak 45,5\%, 45,5\%, dan 9\%. Barium merupakan media kontras yang lebih sering digunakan dengan rasio 8:3 dengan kontras water soluble. Hal ini disebabkan oleh standar operasional prosedur yang diaplikasikan oleh beberapa klinisi. Ultrashort dan short segment memiliki insiden yang sama. Penggunaan barium mendominasi pada studi ini, walaupun kontras water-soluble merupakan media kontras yang lebih dipilih pada bayi usia kurang dari 1 tahun oleh karena memiliki efek terapeutik dan diagnostic. Oleh karena itu penelitian lebih lanjut perlu dilakukan untuk mendukung dan mengubah prespective dalam menegakkan diagnosis.

Kata kunci: penyakit hirschsprung; colon in loop; barium enema; pediatri; radiologi

Correspondence: Anastasia Tjan, Department of Radiology, Faculty of Medicine, Udayana Universty, Sanglah Public General Hospital, Denpasar-Bali. Jalan Diponegoro, Dauh Puri Klod, Denpasar Barat, Dauh Puri Klod, Denpasar Bar, Kota Denpasar, Bali 80113. Email: anz.4191@gmail.com

pISSN:2355-8393 • eISSN: 2599-056x • doi: 10.20473/fmi.v57i1.9857

- Fol Med Indones. 2020;57:41-45 • Received 28 Sept 2018 • Accepted 14 Mar 2019

- Open access under CC-BY-NC-SA license • Available at https://e-journal.unair.ac.id/FMI/

\section{INTRODUCTION}

Hirschsprung disease is a congenital disorder where there is an absence in distal enteric ganglion cells called as Auerbach and meissner plexus that are often found at recto-sigmoid level (Benarroch et al 2014, Weinert \& Rios 2016). This is due to the inhibition of craniocaudal migration of neural crest cells to embryonic 
development and resulting in colorectal relaxation failure (Weinert \& Rios 2016, Schoenwolf et al 2015). These ganglion cells are responsible for normal peristaltis. Therefore, hirschsprung disease will cause functional intestinal obstruction at the aganglionic level (Langer 2012). Hirschsprung has a tonic contraction characteristic at distal colon depicting the lack of $\mathrm{NO}$ or VIP neuron inhibition (Benarroch et al 2014).

In Indonesia, the incidence of Hirschsprung Disease (HD) is not known for sure but several studies conducted resulted with ratio of one in 5000 live births. Indonesia population is 220 million, and the birth rate is 35 per mils. It is predicted that every year, 1540 babies will be born with HD. There was 40 to 60 patients with HD were referred to Cipto Mangunkusumo Hospital Jakarta (Kartono 2004). In addition with HD, they usually presented with other congenital disorder, such as down syndrome and urogenital disorder (Riwanto et al 2011; Kessman 2006). HD frequently affects male compare to female with 4:1 ratio in short segment type of $\mathrm{HD}$, but the gender predilection is almost the same for long segment HD (Weinert \& Rios 2016, Schoenwolf et al 2015, Riwanto et al 2011).

Clinical manifestation of HD started at birth with $99 \%$ of at term newborn have delay meconium passage within 48 hours after birth. HD frequently occurs in the first 6 weeks of life with symptoms, such as abdominal distension, vomiting, and constipation (Benarroch et al 2014, Weinert \& Rios 2016). The pathognomonic sign of $\mathrm{HD}$ is the late passage of meconium with additional abdominal distention and green vomiting respectively as the important symptoms not to be missed. Several newborns may also present with diarrhea and foul smelling stomach as well as fever (Bishop \& Ebach 2017).

HD is classified based on the aganglionic segment. Ultrashort segment (incidence of 13.4\%) is defined when the aganglionic zone is confined to anal sphincter or up to 3-4 cm distal rectum due to its very short aganglionic area the manifestation of this type of HD. Ultrashort segment is not as prominent as the other types, and it can be detected at older age (Meier-Ruge et al 2004).

Short segment HD account for $75 \%$ and is the most common type of HD. Short segment defines where the aganglionic zones reach up to rectosigmoid level. Long segment HD reach up to splenic flexure, while total aganglionic type involves distal ileus from $1 / 3$ transverse colon with incidence rate of $8-10 \%$. Ultra long segment HD is the rarest type if the aganglionic zone reaches small bowel segment and is more than 50 $\mathrm{cm}$ long of aganglionic zone. If the aganglionic zone of
HD involves the entire small intestine, it is called Zuelzers disease (Paterson et al 2015, Moore 2016).

Colon in loop is the examination of choice with water solulable contrast. Contrast enema is both diagnostic and therapeutic. With a soft small cathether introduce to anal spincther without balloon inflation, so that it will not give a false dilatation picture at distal colon. Under fluoroscopy in lateral position, it may give a description of the transisional zone (Weinert \& Rios 2016). Dilatation of sigmoid more than rectum through rectosigmoid index (RSI) calculation will confirm HD if the RSI is below 1, and it is one of HD diagnosis characteristic with contrast enema (Meier-Ruge et al 2004) (Moore 2016).

Histology analysis showed absence of intrinsic parasimpatethic ganglion cells in Auerbach's and Meissner plexus in intestinal wall, associated with increased positive acetylcholinesterase nerve fibers in the aganglionic region of the intestine (Benarroch et al 2014; Paterson et al 2015). This study aimed to give an epidemiological database and current trend analysis from radiological perspective of HD.

\section{MATERIALS AND METHODS}

This study was descriptive prospective study conducted at Radiology department of Sanglah Public General Hospital Bali and involved all patients suspected with HD in 2017. The patients went to colon in loop examination either barium or water-soluble contrast, and it was used for test or measurement. A marker was taped on the anal dimple and about 50-100 cc of contrast, barium 1:8 with saline solution or 1:3 water soluble non-iodinated with saline salutation was used using small catheter which was introduced to anal sphincter without balloon inflation, and the contrast media was injected under fluoroscopy guidance, true lateral, oblique, and antero-posterior (AP) projection photos were taken. The incidence and baseline characteristic, such as age and gender, and contrast media used for colon in loop procedure and HD type from radiological perspective (ultrashort, short, long, and total HD) were the parameters being evaluated in this study. This study defined ultrashort as $4 \mathrm{~cm}$ less aganglionic zone from anal spincther, short segment where aganglionic-hypoganglionic zone reached to sigmoid colon, long segment defined as aganglionichypoganglionic zone up to above sigmoid colon to lienalis flexure, and total aganglionic was beyond that up to distal ileum or ileocaecal junction (Weinert \& Rios 2016).

\section{RESULTS}


All live births at Sanglah Public General Hospital Denpasar-Bali in 2017 were 1018 consisting of 534 males and 468 females. There were 31 patients clinically suspicious with HD.

Table 1. Contrast study result in patient clinically suspicious with HD contrast study

\begin{tabular}{lll}
\hline Contrast study & N & Percentage \\
\hline Hirscprung disease & 22 & $71 \%$ \\
Non Hirscprung disease & 9 & $29 \%$ \\
\hline Total & 31 & $100 \%$ \\
\hline
\end{tabular}

There were 22 patients confirmed HD from colon in loop examination out of 31 patients clinically suspicious of HD (71\%), while 9 patients (29\%) did not show HD from contrast examination. The incidence rate of HD at Sanglah Public General Hospital in 2017 was 2.16\% from all live births.

Table 2. Gender distribution of patients with HD confirmed through colon in loop

\begin{tabular}{lll}
\hline Gender & N & Percentage \\
\hline Male & 17 & $77 \%$ \\
Female & 5 & $23 \%$ \\
\hline Total & $\mathbf{2 2}$ & $\mathbf{1 0 0 \%}$ \\
\hline
\end{tabular}

The gender predilection on this study showed $77 \%$ was male. Male was 3.4 more than female from all patients with HD

Table 3. Age distribution of patients with HD

\begin{tabular}{lll}
\hline Age & N & Percentage \\
\hline 0-<1 Month & 8 & $36.4 \%$ \\
1-12 Months & 5 & $22.7 \%$ \\
1-5 Months & 6 & $27.3 \%$ \\
6-14 Years & 2 & $9.1 \%$ \\
15-25 Years & 1 & $4.5 \%$ \\
\hline Total & 22 & $100 \%$ \\
\hline
\end{tabular}

There was $36.4 \%$ patients confirmed HD through colon in loop examination who showed early manifestation less than 4 weeks old.

Table 4. Contras media used in colon in loop in all patients clinically suspicious of HD

\begin{tabular}{lll}
\hline Contrast Media & $\mathrm{N}$ & Percentage \\
\hline Barium & 24 & $77 \%$ \\
Water soluble & 7 & $23 \%$ \\
\hline TOTAL & 31 & $100 \%$ \\
\hline
\end{tabular}

Table 5. Contrast media used in patient confirmed HD through colon in loop study

\begin{tabular}{lll}
\hline Contrast Media & $\mathrm{N}$ & Percentage \\
\hline Barium & 16 & $73 \%$ \\
Water soluble & 6 & $27 \%$ \\
\hline TOTAL & 22 & $100 \%$ \\
\hline
\end{tabular}

Out of all 31 patients only 7 patients (23\%) using water soluble contrast while $77 \%$ using barium (Table 4). Barium was still the mostly chosen contrast media in all patients confirmed HD through colon in loop study, accounts for $73 \%$ and $27 \%$ of them were using water soluble (Table 5).

Table 6. HD Type from Radiological examination HD

\begin{tabular}{lll}
\hline HD Type & $\mathrm{N}$ & Percentage \\
\hline Ultra short segment & 10 & $45.5 \%$ \\
Short segment & 10 & $45.5 \%$ \\
Long segment & 2 & $9.0 \%$ \\
\hline TOTAL & 22 & $100 \%$ \\
\hline
\end{tabular}

This study demonstrates that ultrashort and short segment has ratio of 1:1 incidence, while long segment HD only $1 / 11$.

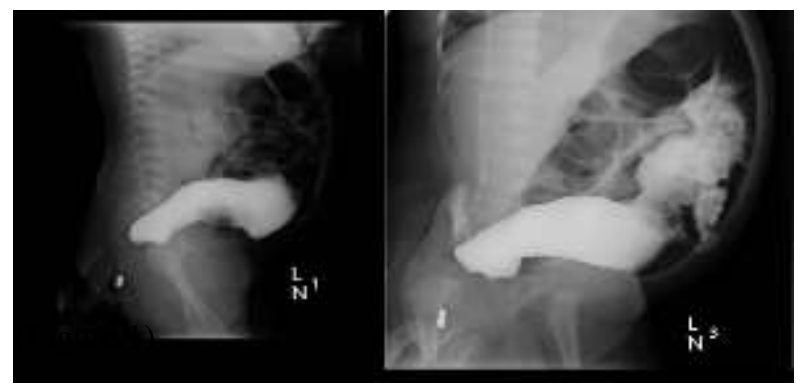

A

B

Figure 1. Water soluble contrast study, Lateral (A) and oblique (B) projections. Aganglionic zone was less than $4 \mathrm{~cm}$, demonstrate ultrashort segment HD.Source : Radiology Departement Sanglah Public General Hospital Bali, published with permission

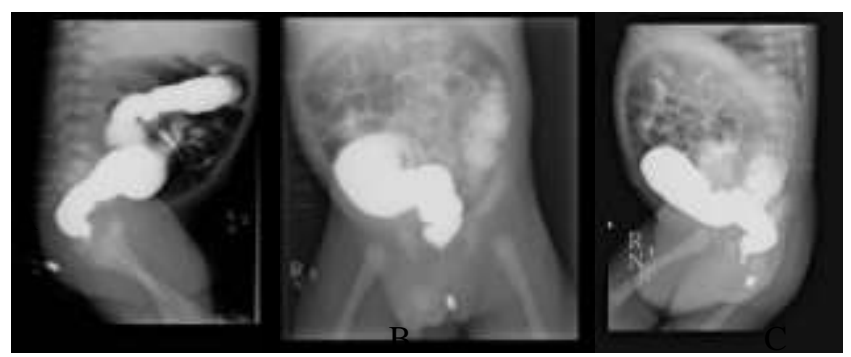

Figure 2. Barium Contrast study, (A) Lateral, (B) AP supine, (C) right oblique, (D) Aganglionic zone at distal sigmoid with cone shape transitional zone, resembles short segment HD. Source : Radiology Departement 
Sanglah Public General Hospital Bali, published with permission

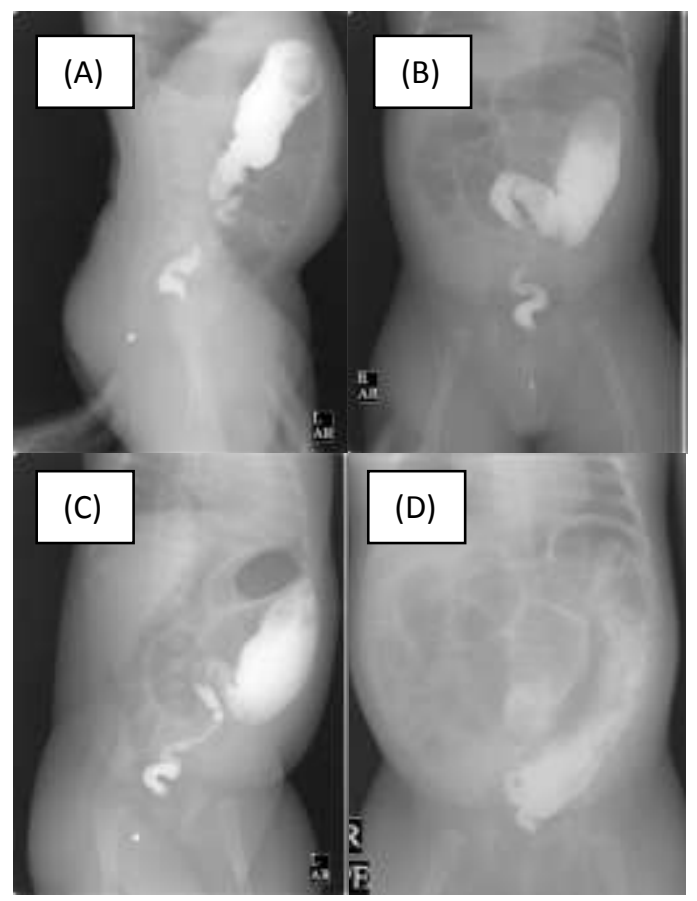

Figure 3. Water soluble contrast study. Aganglionic zone and hypoganglionic zone was seen from rectum to sigmoid and distal colon descenden with transisional zone from mid descenden colon to lienalis flexure. (D) post evacuation 24 hour shows retention and antiperistaltis.

Source: Radiology Departement Sanglah Public General Hospital Bali, published with permission.

\section{DISCUSSION}

Clinical manifestation of HD, such as late meconium passage as well as abdominal distention will lead clinicians to HD diagnosis suspicion. As much as $71 \%$ out all of suspicion confirmed HD diagnosis, while other could be suit differential diagnosis of HD, such as anorectal malformation and multisystem disorder consisting of muscular dystrophy, cystic fibrosis, diabetes mellitus, developmental delay, spinal cord disturbance, meconium plug syndrome (left colon syndrome) celiac disease, meconium ileus, ileal atresia, maternal drug used (Bishop \& Ebach 2017, Moore 2016).

The incidence rate of HD at Sanglah Public General Hospital was $2.61 \%$ with $3.2 \%$ risk for male and $1 \%$ for female. This study showed male predominant. The early manifestation of HD which was less than 1 month old was also in synchronized with prior study, that was the first 6 weeks of living. The use of barium or water soluble contrast is still in debate in several center in Indonesia, while several published studies showed water soluble contrast was the chosen media for baby infant with less than a year of age for both diagnostic and therapeutic (Donnelly 2017, Ralls et al 2017).

Water-soluble contrast could give lavement effect and release the colonic tension (Donnelly 2017, Kraus 2017). Barium contrast was less used due to several other differential diagnosis of HD, such as meconium ileus or meconium plug syndrome where barium would hold up meconium evacuation and camouflage the diagnosis (Donnelly 2017). Water-soluble contrast had given about $87 \%$ sensitivity and $83 \%$ specificity from the study at Oxford UK (Castillo et al 2012). This study showed that barium was still the selected contrast media due to the lack of support from the standard operational procedure in the hospital, where most clinician still believed the use of barium superior to water soluble. This was going to need further discussion with all clinicians involved for the use of water-soluble. Further study stressing the sensitivity and specificity for watersoluble contrast in diagnosing HD in the hospital should be proposed, so that the result could be the backbone for the new standard operational procedure in colon in loop examination for HD.

Short segment HD has to be the most common HD type in literature, while this study reported that ultrashort and short segment contributed the same value, so that long segment and other type were in significant with literature as rare type (Moore 2016).

\section{CONCLUSION}

The incidence rate of HD in 2017 at Sanglah Public Regional Hospital was $2.16 \%$ from all live births with approximately 1.8 cases of HD in every month. HD was manifested in patients less than 4 weeks of age. Male was 3 times for prone to HD compare to female. Ultrashort and short segment HD in the hospital contributed the same number. Barium was used often in the hospital due to standard operational procedure adapted by the clinicians, even tough the most recent update study showed that water soluble was more useful especially for infant less than 1 year due to other different diagnosis which might be camouflaged by the presence of barium. Water-soluble contrast had more advantage for both diagnostic and therapeutic lavement effect. Therefore, further study was recommended to change the perspective of clinicians to be a backbone for the new better standard operational procedure in diagnosing HD. 


\section{REFERENCES}

Benarroch E, Singer W. (2014). Neurodegenerative Autonomic Disorders. In : Benarroch E (eds). Autonomic neurology 1st ed, UK, Oxford University Press.

Bishop W.P, Ebach D.R.(2017) The Digestive System. In : Marcdante K, Kliegman R.M (eds). Nelson Essentials of Pediatric 7th ed, Philadelpia, Elsevier, $\mathrm{p}$ 426.

Castillo F, Stedman J, Franklin JM, ChakrabortY s (2012). The use of water-soluble contrast enemas in the diagnostic pathway of infants who fail to pass meconium, or who are suspected of having Hirschsprung's disease: five-years of experience from Oxford, UK. Vienna, ESR.

Donnelly L (2017). Gastrointestinal. In : Donnelly L (eds). Fundamentals of pediatric imaging. 2nd ed, Philadelphia, Elsevier, p189-191.

Kartono D.(2004) Penyakit Hirschsprung 1st ed, Jakarta, Sagung Seto.

Kessman JMD. (2006) Hirschsprung Disease: Diagnosis and Management. American Family Physician, 74,1319-1322.

Kraus S.J (2017). Hirschsprung Disease.In : Merrow A (eds). Diagnostic Imaging Pediatric. 3rd ed, Philadelpia, Elsevier; p 371.

Langer J C. Hirschsprung Disease. (2012) In: Coran AG, Adzick NS, Krummel TM, Laberge JM, Caldamone A, Shamberger R, (eds). Pediatric Surgery 7th ed, Philadelphia, Elsevier Saunders, p 1265-78.
Meier-Ruge, W., Bruder, E., Holschneider, A., Lochbühler, H., Piket, G., Posselt, H. and Tewes, G. (2004). Diagnosis and Therapy of Ultrashort Hirschsprung's Disease. European Journal of Pediatric Surgery, 14(6), pp.392-397.

Moore S (2016). Hirschsprung disease: current perspectives. Open Access Surgery, 9, 39-50.

Paterson A, Olsen OE, Muller LO (2015). Pediatric Abdominal Imaging. In : Adam A, Dixon AK, Gillard JH, Schaefer-Prokop C, Grainger RG, Allison DJ,

Owens CM (eds). Grainger \& Allison's Diagnostic Radiology. 6th ed, Philadelphia, Elsevier, p 1814.

Ralls MW, Coran AG, Teitelbaum DH, Destro F, Lima M (2017). Hirschsprung's disease. In :Lima M (eds). Pediatric Digestive Surgery. London, Springer, p 267.

Riwanto I, Hamami AH, Pieter J, Tjambolang T, Ahmadsyah I.Penyakit Hirschsprung.(2011) In: Sjamsuhidajat R, Karnadihardja W, Prasetyono TOH, Rudiman R (eds). Buku Ajar Ilmu Bedah 3rd ed, Jakarta: EGG, p 786-8.

Schoenwolf GC, Bleyl SB, Brauer PR, Francis-West PH. Development of the gastrointestinal.(2015) In: Schoenwolf GC, Bleyl SB, Brauer PR, Francis-West PH(eds). Larsen's Human Embryology 5th ed, Philadelpia, Elsevier, p 36371.

Weinert D.M, Rios M C.(2006) Diagnostic Imaging of the Neonate. In : Martin R.J, Fanaroff AA, Wlash MC (eds). Fanaroff and Martin's Neonatal Perinatal Medicine: Diseases of the Fetus and Infant 10th ed, Philadelphia, Mosby Elsevier 